\title{
EDUCATION OF PHYSICAL EDUCATION TEACHERS IN PRIMARY SCHOOL LEVEL IN MACEDONIA AND BULGARIA
}

\author{
Biljana Popeska, Ilija Klincarov, \\ Eleonora Mileva, Nikovski Goran
}

\begin{abstract}
Effectiveness and quality of physical education teaching process is determined by many factors. The key factor in this process is the teacher, particularly his/hers abilities to plan, organize and realize the PE teaching process according to students abilities and interests, following the prescribed curriculum and using all available resources and equipment. Educating future physical education teachers is not a simple process of transmission of knowledge, but it is also a process of training for practical work of students - future teachers. The aim of this research is to analyze and compare the initial education of future PE subject teachers and general classroom teachers that will teach PE in primary schools, studying at the Universities in Macedonia and Bulgaria. The analyses of documentation and comparative analyses are used as a research method. Similarity in some components of the programs are established. Similar study programs and exam requirements could be note at Teaching faculties in Macedonia and Bulgaria that prepare generalist teachers as well as certain similarities between requirements for PE specialists educated at Faculty of sport and PE and National Sport Academy. Different requirements and approaches in realization of teaching practice and practical work of students' future generalist's teachers and PE specialist in Macedonia and Bulgaria can be outlined. Recommendations are given for improving the current situation in both countries.
\end{abstract}

Key words: teacher education, curriculum, physical education, teaching practice

\section{Introduction}

Effectiveness and quality of physical education teaching process is determined by many factors. The key factor in this process is the teacher, particularly his/hers abilities to plan, organize and realize the $\mathrm{PE}$ teaching process according to students abilities and interests following the prescribed curriculum and using all available resources and equipment. Organizations such as EU Commission and UNESCO recognize physical education teachers as key agents for putting physical and sport policies into practice (European Commission, Expert Group on Health-Enhancing Physical Activity, 2015).

The status of PE as school subject and the status of PE teachers are determined by many factors. One of the leading one is the quality of professional education of PE teachers or generalist teachers that deliver physical education. The Recommendation 13 of the EU Work Plan for Sport (2014-2017) clearly states that qualified PE teachers should be preferred at all educational levels. In this regard, the subject of our study is directed on education of teachers delivering PE in primary schools in Macedonia and Bulgaria.

\section{Aim and objectives of the study}

the aim of this study is to analyze and compare the initial education of future generalist teachers that deliver PE in the basic primary education and future PE specialists, studying at the Universities in Macedonia and Bulgaria. The analyses and comparison were based on several key aspects including the following elements: learning programs at the universities - contents, structure, time allocation, exam requirements, ECTS credits; realization of teaching practice; general requirements for teacher's competences; requirements for employment, etc. Similarities and differences between countries related to PETE are used as a foundation for future improvement and for recommendations for future development of PETE. The analyses of documentation and comparative analyses are used as a research method. Several documents from both countries related with teachers education, law regulations and regulations for teachers competences. For the state in Macedonia, the following documents were analyzed: Law for Primary education (2015); Conception for nine-year compulsory primary education (2007); Regulation for teacher's development; PHE curricula from 1 st to $9^{\text {th }}$ grade; study programs of 
the faculties that educate generalist teachers that deliver PHE and PE specialists. From Bulgaria, following documents were analyzed: National strategy for the development of physical education and sport 2012-2022 in Bulgaria, Regulation № 12 (from 01.09.2016) for status and professional education development of teachers, principals and other pedagogical specialists. Special emphasis was given at analyses of the study programs from the both countries, differences regarded contents, maintains of the subject, exam requirements and practical teaching.

\section{Results}

The analyses of teachers education can ' $t$ be made or at least can 't be done completely if we don 't know the general educational perspective and structure in each of analyzed countries and in these frames, the position and state of physical education. In this regard, based on the information from official documents and some national studies realized in Bulgaria (Mileva, 2012) and Macedonia (Malcev \& Popeska, 2017; Popeska, Klincarov, Mitveski \& Nikovski, 2017) and comparative studies including this countries (Klincarov, Popeska, Kovac, Starc \& Mileva 2017) some similarities but also differences regarded the state and structure of educational system and position of $\mathrm{PE}$ in both analyzed countries could be noted. One of the main differences closely related with the object of this study is the general structure of the educational systems in both countries (Klincarov et al., 2017). In Macedonia, the compulsory education starts at the age of six, named as compulsory nine years primary education, realized in three cycles of studies, $\left(1^{\text {st }}-3^{\text {th }}\right.$ grade, $4^{\text {th }}-6^{\text {th }}$ grade and $7^{\text {th }}-9^{\text {th }}$ grade). The first stage of primary education $\left(1^{\text {st }}-5^{\text {th }}\right.$ grade) is known as classroom teaching delivered by generalist teachers. The second stage of primary education is subject teaching $\left(6^{\text {th }}-9^{\text {th }}\right.$ grade) realized by subject teachers. In Bulgaria, the general structure of education system is following: primary education from $1^{\text {st }}$ to $4^{\text {th }}$ grade, pro-gymnasium (Junior High School) from $5^{\text {th }}$ to $7^{\text {th }}$ grade, followed by secondary education from $8^{\text {th }}$ to $12^{\text {th }}$ grade, realized in two stages (high school from $8^{\text {th }}$ to $10^{\text {th }}$ grade and secondary school from $11^{\text {th }}$ to $12^{\text {th }}$ grade). This structure of the educational system within two countries indicates the different education and preparation of the teachers. Comparative studies among two countries (Klincarov et al, 2017), suggest on certain similarities regarded physical education. In both studied countries, physical education is an obligatory school subject in all levels of the educational system, practiced three times per week. In Macedonia, the subject is named "physical and health education", while in Bulgaria is named "physical education and sport". Regarded the number of classes, in Bulgaria the third PE lesson is provided usually as module education out of PE classes.

\section{Education of generalist teachers and preparation for} $P E$ in Macedonia and Bulgaria

The education of the teachers for PE is related with the low requirement for delivery of PE classes in different stages of education. In Macedonia, the subject physical and health education is delivered by generalist teachers in the stage of classroom teaching $\left(1^{\text {st }}\right.$ to $5^{\text {th }}$ grade $)$ and by PE specialist in the stage of subject teaching ( $6^{\text {th }}$ to $9^{\text {th }}$ grade). Similar situation is noted in Bulgaria, where in primary education $\left(1^{\text {st }}-4^{\text {th }}\right.$ grade), PE is delivered by generalist teachers, while in the next stages of education ( $5^{\text {th }}$ to $12^{\text {th }}$ grade), PE specialists realize PE classes.

Regarded teachers education, in Macedonia, generalist teachers are educated at Teaching Faculties in Skopje, Stip and Bitola or at the Faculty of Philosophy - Institute of Pedagogy in Skopje and Tetovo. The professional qualifications at the Teaching faculties are Bachelor in primary education or "graduated primary school generalist teacher" and at the Institutes of Pedagogy is Bachelor in pedagogy or "graduated pedagogic". For both diplomas, 240 ECTS are required. Regarded the preparation for physical and health education there are differences in study programs between Teaching Faculties and Institutes of Pedagogy. Courses for methodic of physical education are included in the study programs at all Teaching Faculties in Macedonia At the Faculty of educational sciences at Goce Delcev University in Stip, during the $5^{\text {th }}$ and $6^{\text {th }}$ semester of study, students learn Basics of Physical and Health education with methodic 1 (6 ECTS) and Physical and health education with methodic 2 (8 ECTS) (http://arhiva.ugd.edu.mk/mk/fon/studiski-programi/oddelenska-nastava.html). Both courses included theoretic lectures, practical exercises, independent work on projects and presentations, observation classes and obligatory practical realization of PHE classes in schools. Special attention is given to practical work and practical realization of PHE classes in schools. These classes are instructed and supervised by teacher - mentor and professor - mentor and obligatory for all students during all $6^{\text {th }}$ semester. Individual realization of PHE classes 
in each grade, positively estimated by the university professor are one of the requirements for final exam from this subject. In the $8^{\text {th }}$ semester, in period of 4 weeks, students have obligatory internship training or "pedagogic work". During this period, students are fully involved in the teaching process in schools, teaching all school subjects including PHE. All students' activities are noted in their "diary for practical work". The whole process is monitored by university teachers and guided by mentor - teacher. This practical work is precondition for getting the final diploma. Related with PHE, beside mentioned courses, students can also learn "Sport and recreation", "Theory and practice of movement games". Similar situation, with different names of the subjects and different maintains by semesters is noted at other Teaching faculties in Macedonia.

Compared with this, at the Faculty of Philosophy, Institute of Pedagogy, beside fundaments of pedagogy, didactics, methodic of educational work, there is no subject related with PHE and methodic and didactical aspects of realization of PHE (http:// www.fzf.ukim.edu.mk/ddtest21/public/uploads/ files/00programinovi/Predmetni_programi_-Pedagogija_finalna.pdf). Similar situation is noted for art and music education as well.

Similar situation as one presented for education of generalist teachers at the Teaching faculties in Macedonia is also noted in Bulgaria. Namely, the generalists teachers in Bulgaria who teach PE in primary school study the specialties Pre-school and Primary school pedagogy or Primary school pedagogy with Foreign language in the Universities in Bulgaria to Faculties of Pedagogy. The professional qualifications are: Bachelor in pedagogy pre-school and primary school teacher or primary school teacher with foreign language. All regular students study the module Theory of Physical education for one semester in the second study year between 3 and 5 ECTS. In the third study year the generalist students learn Methodic of Physical education (5 ECTS - lectures, seminars and ongoing pedagogical practice) (http://uni-sz.bg/). During the practice each student observes and when it is possible he/she provides part or whole PE lesson under the supervision of teacher mentor and after consultations with the university assistant. In the $8^{\text {th }}$ semester (last) is organized the pre-graduate internship/training, which takes place in two cycles: in elementary school - 4 weeks and in kindergarten
- 4 weeks. During the internship, future primary school teachers teach lessons on all subjects, including PE. According to the new Regulation № 12, each mentor teacher has 2 students allocated. The internship (16.5 credits) runs under the guidance of an assistant who keeps in touch with mentor teachers. Each cycle ends with a state practical examination before a state exam committee. An oral exam is also held by the State Examination Commission on private methodic, with questions in the field of PE (being equal to those in mathematics, etc.). There are four state examinations: written theoretical exam (general in pedagogy and psychology), oral exam on Methodology of pre-school and primary school education and two practical - in kindergarten and elementary school. Other disciplines offered to the bachelors as optional are: "Motor training and APA", "Motor training and Kinesitherapy" "Sports animation", "Bulgarian folks dances" with 2 to 3 credits.

\section{Education of PE specialists in Macedonia and Bulgaria}

In Macedonia and Bulgaria, PE specialist are delivering PE classes in the second stage of primary education $\left(6^{\text {th }}-9^{\text {th }}\right.$ grade in Macedonia) or in the secondary schools ( $5^{\text {th }}$ to $12^{\text {th }}$ grade) in Bulgaria. In Macedonia, the oldest and leading institution in preparation of PE specialist is the Faculty of physical education, sport and health at the "St. Cyril and Methodius" University in Skopje. In the last few years, such studies are also realized at the Faculty of Sport at the University in Tetovo. Related with preparation for practical realization of PHE classes, students are prepared during 4 years studies at the study program "Physical and health education", earning totally 240 ECTS. The professional qualification that students achieve is Bachelor in Kinesiology. Study program contains obligatory and optional courses from different areas of kinesiology. Students learn subjects related to different sports: gymnastics, sport games, martial arts, recreation; subjects with bio - medicine background; background in humanities - pedagogy, psychology, sociology; practical teaching in summer and winter sports etc. The subject dedicated to learning of methodic and didactic aspects of PE teaching process is named "Didactics of physical and health education". This course is realized in the final year of studies, evaluated with 8 ECTS. Students are included in theoretic lectures, practical exercises in schools (observation and practical realization of PHE classes) and project activities The pre - exam requirement for final exam 
are very similar with the practical work of students at the Teaching faculties. It includes observation classes, written preparations for the class, tandem realization of PHE classes in schools, independent realization, pedagogical work etc.

Similar, in Bulgaria in the secondary schools there are qualified specialists in physical education. In all schools in Bulgaria from $5^{\text {th }}$ to $12^{\text {th }}$ grade, PE teachers are specialists, who have graduated the National Sports Academy (Peneva \& Mileva, 2005), or specialized in Physical Education at the Pedagogical Faculties of the Universities in Veliko Tarnovo, Blagoevgrad, Shumen, Plovdiv and Sofia. The Faculty of Physical Education at the National Sports Academy in Sofia has been the core of the National Sports Academy in Bulgaria since its establishing in 1942 (then as Higher Institute for Physical Culture) (Mileva, 2011). The professional area is currently defined as Pedagogy of Physical Education with Physical Education Major. Bachelor's Degree programs last for eight semesters in regular mode of study and ten semesters in part-time education. Both modes lead to obtaining 240 ECTS credit points. Graduation from the Faculty of Physical Education provides professional qualification "Teacher in physical education". Using modules of general preparation, students have the opportunity to obtain an additional qualification along with their major - Coach in sport or Sport manager, Sports animator, Coach in APA. During their studies the graduates of the Faculty can also specialize their initial qualification in post-graduate programmes (www.nsa.bg).

Regarded the structure of the study program, it contains Compulsory general theoretic subjects; compulsory specialized subjects, elective subjects theoretical and practical, optional subjects; training courses in skiing, water sports, tourism, orientation and camping; Teaching practice at school and finaly state examination or defending a diploma thesis. Teaching methods at the Faculty include lectures and individual work as well as participation in projects development and implementation. Practical training is a key component of all qualification programmes. Training structures and programmes for obtaining a degree in physical education and teacher qualification are entirely in compliance with the European standards and requirements. The Faculty participates actively in all European activities intended to align the European higher education structure in sport science.
Studying at the Faculty of Physical Education at NSA in Sofia and at Faculty of PE sport and health in Skopje, encompasses the three educational and qualification degrees - Bachelor, Master and Doctor. The formal university education is only one of the segments of education of future teachers. Related with the professional competences of the teachers, in Macedonia they are defined in the Regulations for basic professional competences of primary and secondary school teachers (2015), defined in the Low for primary and secondary schools (2015). In Bulgaria, the State Educational Standards for Status and Professional Education development of teachers, principals and other pedagogical specialists are defined in Regulation № 12 (from 01.09.2016).

\section{Discussion}

based on the analyses of the national strategic documents for development of PE and of the study programs of the faculties that prepare generalist teachers and PE specialist from the both countries, similarities in some components of the programmes are established. Similarities are noted between study programs of the Teaching faculties in Macedonia and Bulgaria regarded the preparation of generalist teachers for delivering physical education. Similarities are noted in the contents, practical teaching and work, exam requirements. Exception is the profile of generalist teachers in Macedonia educated at Faculty of Philosophy, Institute of Pedagogy that can be also employed as generalist teachers but have no subject for methodic and didactic aspects of physical education. Existence of such profile of teachers with no specific education for $\mathrm{PE}$, music and art in their university education have a great negative effect in their future work with children in primary school. From the aspect of the quality of delivery of PE classes by generalist teachers, lot of problems are noted in both countries (Klincarov et al, 2017). Possible reasons should be analyzed in wider context including conditions in schools, material facilities, structures of PE curricula, and possibilities for continuous professional development, improved cooperation with faculties for Sport and Physical education / National Sport Academy etc.

Different requirements and approaches in realization of teaching practice, the exam criteria and evaluation of PE specialists in Macedonia and Bulgaria can be outlined. In this regard, what can be done as a future step is international agreements and learning practices connect the Faculty of Phys- 
ical Education with similar higher education institutions and faculties all over Europe. Great opportunities for student and teacher exchange exist especially within the framework of mobility under European educational programmes.

\section{Conclusions}

Based on the obtained results, we highlighted the positive teaching experiences and teaching practices, but also determined the gaps that should be corrected and improved. The analyses suggested on existing correlation between the current curriculum for professional training of PE teachers in the universities in Bulgaria and Macedonia with the proposed European model curriculum for training of these professionals.

The given recommendations are pointed toward certain changes that could be made in order to improve the initial education of teachers for physical education. The future steps can be pointed toward increase of hours for practical teaching and work, clearly defined standards and requirements for teacher professional development, greater cooperation between the Teaching faculties and the Faculties for Sport and PE/the National Sports Academy in the process of initial preparation of generalist teachers for PE, improved cooperation between these institutions and governmental bodies responsible for education on state level, creating a network of teachers involved in delivery of PE for sharing experiences and good practices etc.

\section{References}

Bureau for the development of education (2007). Physical education curriculum for first - ninth grade in nine year primary education, Skopje: Macedonian ministry of education.

Conception for nine years compulsory education in Republic of Macedonia (2007). Bureau for the development of education. Skopje: Ministry of education

EU Work Plan for Sport 2014-2017 (2015). Expert Group on Health- enhancing physical activity, European Commission.

Klincarov I., Popeska, B., Kovac, M., Mileva, E. and Starc, G. (2017), Comparative study on the state and the status of primary physical education in Macedonia, Slovenia and Bulgaria, in Changes in Childhood and Adolescence: Current Challenges for Physical Education, Proceedings of the 12th FIEP European Congress, 2017, Logos Verlag, Berlin, pp. 89-90.

Наредба № 12 от 01.09.2016 г. за статута и професионалното развитие на учителите, директорите и другите педагогически специалисти available at: http://zareformata.mon.bg/documents/ naredba_12_01.09.2016_prof_razvitie_uchiteli.pdf (accessed 20 September 2017).

Национална стратегия за развитие на физическото възпитание и спорта в Република България 2012$2022 \mathrm{http}: / / \mathrm{mpes}$. government.bg/Documents/Documents/Strategii/Strategia_2012-2022.pdf (accessed at 10 September 2017).

Учебни програми по физическо възпитание и спорт (Uchebni programi po fizichesko waspitanie i sport), available at: www.mon.bg (accessed 10 September 2017). Учебен план на специалност Физическо възпитание ОКС „Бакалавър” при Национална спортна академия (Ucheben plan na spezialnost Fizichesko vaspitanie OKS Bakalavar pri Natzionalna sportna akademiya), available at: www.nsa.bg (accessed 20 September 2017).

Предучилищна и начална училищна педагогика, Тракийски университет, Педагогически факултет (Preduchilishtna i nachalna uchilishtna pedagogika, Trakiyski universitet), available at: http://uni-sz.bg/ (accessed 21 September 2017).

Malcev, M., Popeska, B. (2017). Primary School Physical Education in Republic of Macedonia -Condition and Challenges, in "Physical Education in Primary School: Researches - Best Practices - Situation", (Editors: D. Colella, B. Antala, S. Epifany); Publisher: Pensa Multimedia in cooperation with University of Foggia.

Mileva, E. (2011), Vocational qualification and training of physical education teachers at the National Sports Academy in Bulgaria, in Proceedings book Physical Education in the $21^{\text {st }}$ century - pupils' competencies, $6^{\text {th }}$ FIEP European Congress, Porec, June 18-21, 2011, pp. 320-325. Милева, Е. (2012), Европейски измерения на спортнопедагогическото образование, Авангард Прима, София (Mileva, Е. (2012), Evropeyski izmerenija na sportnopedagogicheskoto obrazovanie, Avangard Prima, Sofia).

Peneva, B., Mileva, E. (2005), Social problems of Bulgarian School Physical Education (historical view), FIEP Bulletin, Vol. 75, 1, pp. 69-72.

Peneva, B., Buyuklieva, A. (2016), Challenges in front of the profession teacher of physical education, Physical Education, Sport, Kinesitherapy Research Journal, 1(2), Art.12, pp. 58-61.

Popeska, B., Klincarov, I., Mitevski, O. and Nikovski, G. (2017). Common problems in realization of physical education teaching process in Republic of Macedonia. In Proceeding book Changes in Childhood and Adolescence: Current Challenges for Physical Education, Proceedings of the 12th FIEP European Congress, 2017, Logos Verlag, Berlin. Закон за наставници во основно образование (2015). Министерство за образоавние и наука. Available at http://mon.gov.mk/images/documents/zakoni/zakon-za-nastavnici-osnovno-sredno-2015.pdf (accessed 15 September 2017).

http://arhiva.ugd.edu.mk/mk/fon/studiski-programi/ oddelenska-nastava.html (accessed 10 September 2017) http://www.fzf.ukim.edu.mk/ddtest21/public/uploads/ files/00programinovi/Predmetni_programi_-_Pedagogija_finalna.pdf (accessed 10 September 2017) http://ffosz.ukim.edu.mk/Nastavni_programi/Nastaven Plan_FSZO_2017_18.pdf (accessed 10 September 2017) 